\title{
Pelvic Pain and Associated Characteristics Among Women in Northern Mexico
}

By Hilda

García-Pérez,

Sioban D. Harlow,

Christine A.

Erdmann and

Catalina Denman

Hilda García-Pérez is assistant professor, Department of Transborder Chicana/o and Latina/o Studies, Arizona State University, Tempe, AZ, USA.

Sioban D. Harlow is professor, Department of Epidemiology, School of Public Health, University of Michigan, Ann Arbor, MI, USA. Christine A.

Erdmann is associate professor, Medical University of the Americas,

Charlestown, Nevis, West Indies. Catalina Denman is researcherprofessor, Department of Health and Society, El Colegio de Sonora, Hermosillo, Mexico.

\begin{abstract}
CONTEXT: Until recently, the reproductive health agenda has focused on a restricted number of morbidity indicators, particularly those associated with life-threatening diseases. However, gynecologic morbidities that are a source of pelvic pain, although not life-threatening, do impose a substantial burden because of their potential to reduce women's overall well-being.
\end{abstract}

METHODS: In 2005, a cross-sectional population-based study was conducted in Hermosillo, Mexico, to assess selfreported pelvic pain conditions in a random sample of 1,307 women aged 25-54. The 12-month prevalence of each condition was calculated, and logistic regression was used to assess the association between pelvic pain and social, demographic, anthropometric and reproductive characteristics, and other medical conditions.

RESULTS: The 12-month prevalence of pelvic pain during menstruation among 1,007 menstruating women was $40 \%$. Pelvic pain during or after sexual intercourse was reported by $12 \%$ of the 1,183 sexually active respondents. Among 1,201 nonpregnant women, $6 \%$ reported chronic pelvic pain. In adjusted analyses, younger age (25-34 years) and having a history of STIs or pelvic inflammatory disease (PID) were associated with an increased risk of pain during menstruation and chronic pelvic pain (odds ratios, 1.6-3.1). An interaction term for younger age and history of STIs or PID was associated with an elevated risk of intercourse-related pelvic pain (6.4). Chronic pelvic pain and pain during menstruation were more frequently reported as interfering with daily activities than was intercourse-related pelvic pain. The proportion of women who had talked with a physician about their condition was highest among those with chronic pelvic pain (40\%).

CONCLUSION: Pelvic pain associated with menstruation, pelvic pain during or after sexual intercourse, and chronic pelvic pain are common complaints among Mexican women of reproductive age. Health care providers should pay greater attention to these conditions.

International Perspectives on Sexual and Reproductive Health, 2010, 36(2):90-98

Policymakers and researchers have highlighted the urgency of developing a broader approach to addressing women's reproductive health needs and to identifying health policy priorities, especially in less-developed nations. ${ }^{1}$ Although the existing concept of reproductive health calls for identifying women's health needs, the organizing principle of current health policies and research in this area continues to emphasize illness over health, which reinforces a narrow conceptualization of women's health needs. ${ }^{1}$ Until recently, reproductive health advocates have focused on a restricted number of morbidity indicators, particularly those associated with lifethreatening diseases. Few studies have paid attention to life-enhancing aspects of sexual and reproductive health, such as enjoyable sex, or health-related quality of life among women of childbearing age. ${ }^{2}$ Yet, the concept of reproductive health extends beyond mortality and should explicitly include a lack of reproductive morbidity and associated disabilities, as well as the full range of conditions, experiences and circumstances that affect women's quality of life across their reproductive life cycle.

Because, in part, of this emphasis on life-threatening dis- eases, the gynecologic conditions that cause pelvic pain traditionally have been neglected in research and service delivery programs in Mexico. ${ }^{3}$ Reproductive health programs and research have focused mainly on maternal and child health, contraception, STIs, and cervical and breast cancer. ${ }^{3}$ However, pelvic pain is a major gynecologic complaint among women of reproductive age: ${ }^{4-7}$ some women begin experiencing it as soon as they begin menstruating. Chronic pelvic pain and painful sexual intercourse have been associated with impairments in women's sexual and social functioning. ${ }^{5}$ Occurrence of multiple pelvic pain conditions has been reported in some studies. 6,8

Although the negative impact of pelvic pain on women's overall health has been documented in developed countries, little is known about the prevalence and the burden of pelvic pain conditions in less-developed countries. ${ }^{9}$ According to a World Health Organization (WHO) systematic review, the prevalence of pelvic pain associated with menstruation is estimated at $17-81 \%, 9,10$ of pelvic pain during or after sexual intercourse, at $8-22 \%,{ }^{9}$ and of chronic pelvic pain, at 2-24\%. ${ }^{9}$ Differences in definitions, questionnaire design and study populations may account 
for most of this variation. In Mexico, only a handful of studies, most of which were not population-based, have estimated the population burden of pelvic pain conditions. ${ }^{11-15}$

In this study, we sought to determine the 12-month prevalence of conditions causing pelvic pain that do not threaten women's life directly but impose a substantial burden because of their potential to disrupt daily activities and reduce women's overall well-being. This research estimated the extent to which women in northern Mexico were affected by chronic pelvic pain and by pelvic pain associated with menstruation and sexual intercourse.

\section{DATA AND METHODS Study Setting}

Hermosillo is the capital city of Sonora, a state located along Mexico's border with the United States. This area of the country is one of the more urbanized and industrialized in Mexico, and has an economy that is based on export-oriented industries and services. In 2005, more than $95 \%$ of the region's population lived in municipalities classified as having very low to low levels of socioeconomic marginalization. ${ }^{16}$ With a population of 702,000 in 2005, Hermosillo is one of the urban and economic hubs of Sonora. Currently, about one-quarter of the population of Sonora resides in Hermosillo, which has an annual growth rate of $3 \% .^{17}$

Overall, Sonora fares better than Mexico as a whole in several demographic and reproductive indicators. In 2009, women's life expectancy at birth was 77.8 years in Sonora versus 77.6 years nationally. ${ }^{18}$ Infant mortality was 12.1 deaths per 1,000 live births versus 14.6 per 1,000 nationally. ${ }^{18}$ Sonora has a very high percentage of women using contraceptives, $80 \%$ among women living with a sexual partner compared with $71 \%$ nationally. ${ }^{19}$

Incomplete coverage and high levels of stratification and centralization are the features that best describe the Mexican health care system. ${ }^{20}$ Different social groups are segregated into separate health subsystems, which cover populations with and without medical insurance. The Mexican Institute of Social Security (IMSS) and the Social Security Institute to the Service of Public Workers (ISSSTE) are the largest public health subsystems providing health care and other benefits for the formally employed and their families. The rest of the Mexican population is served mainly by the state health system and the private sector.* In 2005, it was estimated that $67 \%$ of the population in Sonora had some type of public medical insurance. Of those with medical insurance, $67 \%$ were covered by IMSS, 15\% by Popular Security (voluntary insurance offering limited coverage for poor families) and 9\% by ISSSTE; the remaining $9 \%$ were covered by the Mexi-

*It is estimated that less than $3 \%$ of the Mexican population has private health insurance (source: Organisation for Economic Co-operation and Development [OECD], OECD Reviews of Health Systems-Mexico, 2005, <http://www.nmsu.edu/ bec/BEC/Readings/7.OECD\%20Reviews\%20\%of $\% 20$ Health\%20Systems_Mexico.pdf>, accessed June10,2010). can Oil Company, the Navy, the Army or other public subsystems. ${ }^{21}$ Of the population without medical insurance, most are served by the Sonora state health department, through community clinics and public hospitals. ${ }^{22}$

\section{Sample}

In 2005, a random sample of 1,307 women aged 25-54 were interviewed as part of a cross-sectional, populationbased survey of gynecologic morbidity conducted in Hermosillo. First, 29 census tracts were randomly selected from among 234 residential census tracts with at least 50 inhabitants. In each selected census tract, 10 census blocks were randomly selected and houses on these blocks were surveyed sequentially until approximately 45 eligible women per census tract had been interviewed (range, 6-78 women). A short household screening questionnaire was used to identify women aged 25-54 who were permanent residents of Hermosillo. In households that included two or more eligible women, one woman was randomly selected for interview. A total of 1,420 eligible women were identified, of whom 1,307 were interviewed (92\%), 49 declined to participate (3\%) and 64 could not be contacted ( $5 \%$ ). The study was approved by the Institutional Review Boards of the University of Michigan, Arizona State University and El Colegio de Sonora in Mexico. Written informed consent was obtained from each woman.

\section{Measures}

This study used a face-to-face interview to assess the proportion of women reporting menstrual pain, pelvic pain during or after intercourse, and chronic pelvic pain using a Spanish translation of a shortened version of the

TABLE 1. Selected characteristics of pelvic pain conditions among women aged 25-54 in Hermosillo, Mexico, 2005

\begin{tabular}{|c|c|c|c|}
\hline Characteristic & $\begin{array}{l}\text { Menstrual } \\
\text { paint }\end{array}$ & $\begin{array}{l}\text { Pain with } \\
\text { intercourse }\end{array}$ & $\begin{array}{l}\text { Chronic } \\
\text { pelvic } \\
\text { pain§ }\end{array}$ \\
\hline ALL WOMEN & $(\mathrm{N}=1,007)$ & $(\mathrm{N}=1,183)$ & $(\mathrm{N}=1,201)$ \\
\hline With condition (\%) & $39.9(36.9-43.0)$ & $12.3(10.5-14.4)$ & $6.4(5.1-8.0)$ \\
\hline \multicolumn{4}{|l|}{ Pain severity (\%)†† } \\
\hline Slight & $15.5(13.4-17.9)$ & $6.7(5.4-8.3)$ & $2.4(1.7-3.5)$ \\
\hline Moderate & $16.4(14.2-18.9)$ & $4.6(3.6-6.1)$ & $3.2(2.3-4.4)$ \\
\hline Severe & $7.9(6.3-9.7)$ & $1.0(0.6-1.8)$ & $0.7(0.3-1.4)$ \\
\hline \multicolumn{4}{|l|}{ WOMEN WITH } \\
\hline CONDITION & $(\mathrm{N}=402)$ & $(\mathrm{N}=146)$ & $(\mathrm{N}=77)$ \\
\hline \multicolumn{4}{|l|}{ Age at onset (\%)¥\# } \\
\hline$\leq 24 \mathrm{yrs}$ & 72.2 & 29.0 & na \\
\hline$\geq 25$ yrs. & 27.7 & 71.0 & na \\
\hline $\begin{array}{l}\text { Mean yrs.since } \\
\text { first symptoms } \neq \neq\end{array}$ & $15.8(\mathrm{SD}=10.2)$ & $5.8(\mathrm{SD}=6.3)$ & na \\
\hline
\end{tabular}

†Among women who had had at least one menstrual period in the last 12 months. ¥Among women who had had at least one sexual partner in the last 12 months. §Among women who had not been pregnant in the previous 12 months. †+Data are missing for two women on mentrual pain and chronic pelvic pain. ¥¥Data are missing for six women on menstrual pain and one woman on pain with intercourse. Notes: Unless otherwise noted, figures in parentheses are $95 \%$ confidence intervals. na=not applicable. $S D=$ standard deviation. 
TABLE 2. Percentage of women having pelvic pain conditions, and the crude odds ratios (and $95 \%$ confidence intervals) of having each condition from logistic regression analyses, according to selected characteristics, by condition

\begin{tabular}{|c|c|c|c|c|c|c|c|c|c|}
\hline \multirow[t]{2}{*}{ Characteristic } & \multicolumn{3}{|c|}{ Menstrual pain† } & \multicolumn{3}{|c|}{ Pain with intercourse $\neq$} & \multicolumn{3}{|c|}{ Chronic pelvic pain§ } \\
\hline & $\mathrm{N}$ & $\%$ & OR $(95 \% \mathrm{Cl})$ & $\mathrm{N}$ & $\%$ & OR $(95 \% \mathrm{Cl})$ & $\mathrm{N}$ & $\%$ & OR $(95 \% \mathrm{Cl})$ \\
\hline \multicolumn{6}{|l|}{ DEMOGRAPHIC } & \multicolumn{4}{|c|}{ Age (yrs.) } \\
\hline $25-34$ & 450 & 45.3 & $1.50(1.16-1.93)$ & 436 & 17.4 & $2.04(1.44-2.89)$ & 397 & 10.3 & $2.45(1.54-3.91)$ \\
\hline$\geq 35$ (ref) & 557 & 35.5 & 1.00 & 747 & 9.4 & 1.00 & 804 & 4.4 & 1.00 \\
\hline \multicolumn{10}{|l|}{ Marital status } \\
\hline Single & 136 & 39.7 & $1.01(0.69-1.47)$ & 88 & 5.6 & $0.41(0.1-1.04)$ & 142 & 3.5 & $0.51(0.20-1.31)$ \\
\hline Married/living as married (ref) & 792 & 39.4 & 1.00 & 1,026 & 12.6 & 1.00 & 941 & 6.6 & 1.00 \\
\hline Divorced/separated/widowed & 79 & 45.5 & $1.28(0.81-2.05)$ & 69 & 15.9 & $1.30(0.66-2.55)$ & 118 & 8.4 & $1.31(0.65-2.63)$ \\
\hline \multicolumn{10}{|l|}{ REPRODUCTIVE } \\
\hline \multicolumn{10}{|l|}{ Age at sexual debut (yrs.) } \\
\hline $10-14$ & 42 & 57.1 & $2.26(1.20-4.26)$ & 51 & 23.5 & $2.54(1.28-5.02)$ & 46 & 6.5 & $1.16(0.35-3.09)$ \\
\hline $15-17$ & 239 & 46.0 & $1.45(1.07-1.47)$ & 279 & 15.1 & $1.46(0.98-2.17)$ & 278 & 9.0 & $1.65(0.99-2.74)$ \\
\hline$\geq 18$ (ref) & 686 & 37.0 & 1.00 & 852 & 10.8 & 1.00 & 834 & 5.6 & 1.00 \\
\hline No sexual debut & 40 & 35.0 & $0.91(0.47-1.78)$ & na & na & na & 43 & 4.7 & $0.81(0.19-3.48)$ \\
\hline Missing & 0 & & & 1 & & & 0 & & \\
\hline \multicolumn{10}{|l|}{ Type of birth } \\
\hline Vaginal (ref) & 524 & 38.3 & 1.00 & 41 & 10.7 & 1.00 & 661 & 6.5 & 1.00 \\
\hline Cesarean & 258 & 40.7 & $1.10(0.81-1.49)$ & 662 & 15.9 & $1.58(1.06-2.35)$ & 272 & 6.2 & $0.95(0.53-1.71)$ \\
\hline Both & 145 & 42.0 & $1.16(0.80-1.69)$ & 294 & 11.3 & $1.06(0.63-1.78)$ & 182 & 6.0 & $0.92(0.46-1.83)$ \\
\hline No births & 80 & 43.7 & $1.25(0.77-2.01)$ & 185 & 17.0 & $1.71(0.73-4.00)$ & 86 & 6.9 & $1.07(0.44-2.61)$ \\
\hline Missing & 0 & & & 1 & & & 0 & & \\
\hline \multicolumn{10}{|l|}{ IUD use } \\
\hline Yes & 107 & 45.8 & $1.30(0.87-1.95)$ & 110 & 20.0 & $1.91(1.15-3.16)$ & 103 & 6.8 & $1.07(0.47-2.39)$ \\
\hline No (ref) & 900 & 39.2 & 1.00 & 1,073 & 11.5 & 1.00 & 1,098 & 6.3 & 1.00 \\
\hline \multicolumn{10}{|l|}{ History of STI/PID } \\
\hline Yes & 126 & 57.9 & $2.31(1.58-3.38)$ & 153 & 24.1 & $2.71(1.78-4.13)$ & 151 & 16.5 & $3.80(2.28-6.34)$ \\
\hline No (ref) & 880 & 37.2 & 1.00 & 1,028 & 10.5 & 1.00 & 1,049 & 4.9 & 1.00 \\
\hline Missing & 1 & & & 2 & & & 1 & & \\
\hline \multicolumn{10}{|l|}{ History of uterine fibroids } \\
\hline Yes & 38 & 57.9 & $2.13(1.10-4.11)$ & 70 & 17.1 & $1.51(0.79-2.88)$ & 76 & 14.4 & $2.70(1.36-5.36)$ \\
\hline No (ref) & 962 & 39.2 & 1.00 & 1,105 & 12.0 & 1.00 & 1,120 & 5.8 & 1.00 \\
\hline Missing & 7 & & & 8 & & & 5 & & \\
\hline \multicolumn{10}{|l|}{ MEDICAL } \\
\hline \multicolumn{10}{|l|}{ History of colitis } \\
\hline Yes & 321 & 50.4 & $1.91(1.46-2.51)$ & 393 & 17.8 & $2.08(1.54-2.97)$ & 402 & 8.7 & $1.71(1.07-2.72)$ \\
\hline No (ref) & 683 & 34.7 & 1.00 & 787 & 9.4 & 1.00 & 796 & 5.3 & 1.00 \\
\hline Missing & 3 & & & 3 & & & 3 & & \\
\hline \multicolumn{10}{|l|}{ Chronic urinary tract infections } \\
\hline Yes & 380 & 45.5 & $1.45(1.12-1.89)$ & 483 & 16.9 & $2.06(1.45-2.92)$ & 473 & 9.0 & $2.38(1.28-3.24)$ \\
\hline No (ref) & 626 & 36.4 & 1.00 & 698 & 9.0 & 1.00 & 727 & 4.6 & 1.00 \\
\hline Missing & 1 & & & 2 & & & 1 & & \\
\hline \multicolumn{10}{|l|}{$\begin{array}{l}\text { ANTHROPOMETRIC } \\
\text { Body mass index }\left(\mathbf{k g} / \mathbf{m}^{\mathbf{2}}\right)\end{array}$} \\
\hline$<25$ & 238 & 34.0 & 1.00 & 245 & 11.4 & 1.00 & 261 & 6.5 & 1.00 \\
\hline$\geq 25$ & 757 & 41.8 & $1.39(1.03-1.89)$ & 924 & 12.7 & $1.13(0.73-1.75)$ & 926 & 6.4 & $0.96(0.55-1.68)$ \\
\hline Missing & 12 & & & 14 & & & 14 & & \\
\hline \multicolumn{10}{|l|}{ Height (cm) } \\
\hline$\leq 150$ & 73 & 39.7 & $0.98(0.60-1.60)$ & 85 & 11.7 & $0.93(0.47-1.84)$ & 92 & 11.9 & $2.12(1.07-4.17)$ \\
\hline$>150$ (ref) & 924 & 40.0 & 1.00 & 1,086 & 12.5 & 1.00 & 1,097 & 6.0 & 1.00 \\
\hline Missing & 10 & & & 12 & & & 12 & & \\
\hline
\end{tabular}

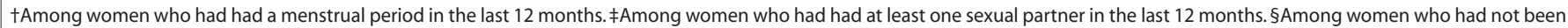
pregnant in the last 12 months. Notes: $r$ f=reference group. na=not applicable.

Oxfordshire Women's Health Study questionnaire. ${ }^{8}$ Social and demographic variables included age, education and marital status.

- Pelvic pain and pain severity level. The study describes the 12-month prevalence of three types of pelvic pain: pain in the lower abdomen during menstruation; pain during sexual intercourse or the subsequent 24 hours; and chronic pelvic pain, defined as a constant or intermittent pain below the belly button or in the female organs over a period of six months or longer, excluding pain associated with menstruation, sexual intercourse or pregnancy. ${ }^{8}$ The severity of pain was assessed using three categories (very 
slight/slight, moderate and severe). Participants were asked to indicate whether pelvic pain disrupted their daily activities in work, home and social life.

- Reproductive and medical conditions. In this analysis, we consider reproductive and medical variables that have been associated with pelvic pain in previous studies in other populations. ${ }^{23}$ Endometriosis is not included in this analysis because few women reported having this condition; it is likely that endometriosis is underreported in our data. ${ }^{24}$ Reproductive and medical conditions were evaluated by asking, "Has a doctor told you that you suffer from any of the following illnesses or conditions?" The list of possible medical conditions included chronic urinary tract infections (chronic cystitis and recurrent kidney infections), colitis, uterine fibroids, STIs and pelvic inflammatory disease. In addition, we asked about age at sexual debut; parity; history of cesarean section; and contraception, including the use of IUDs.

- Anthropometrics and body mass index. Body weight in kilograms was assessed by a digital scale, with participants wearing light clothing and no shoes. Height was measured using a dressmaker's measuring tape and recorded to the nearest half centimeter. Body mass index (BMI) was then calculated $\left(\mathrm{kg} / \mathrm{m}^{2}\right)$.

- Health care resource utilization. To assess health care utilization, we asked whether respondents had visited a physician or used pelvic pain-related medications in the last 12 months, whether the woman's condition had been diagnosed and whether she had medical insurance.

\section{Analysis}

All analyses were performed using SAS version 8.2. We calculated the proportion (with $95 \%$ confidence interval) of women who had suffered from each type of pelvic pain over the last 12 months. Menstrual pain was assessed in the subgroup of women who reported having had at least one menstrual period in the last 12 months ( $\mathrm{N}=1,007)$, pain with intercourse in the subgroup who reported having had a sexual partner in the last 12 months $(\mathrm{N}=1,183)$ and chronic pelvic pain in the subgroup of women who had not been pregnant during the last 12 months $(\mathrm{N}=1,201)$. Descriptive statistics were calculated, including frequencies and measures of central tendency and dispersion. Crude and adjusted logistic regression analyses were performed to estimate the odds of having menstrual pain, pain with intercourse and chronic pelvic pain, given demographic, reproductive, anthropometric, lifestyle and medical variables. Odds ratios with 95\% confidence intervals were calculated, and all possible interactions were evaluated.

\section{RESULTS}

\section{Personal Characteristics and Pain}

The mean age of the participants was 38.5 years (standard deviation, 8.4 years). Overall, 33\% had completed high school or some college, $40 \%$ had completed at least some middle school and $27 \%$ had less than a middle school ed-
TABLE 3. Adjusted odds ratios (and 95\% confidence intervals) from multiple logistic regression analyses to identify associations between selected characteristics and pelvic pain conditions, by condition

\begin{tabular}{|c|c|c|c|}
\hline Characteristic & Menstrual pain & Pain with intercourse & Chronic pelvic pain \\
\hline \multicolumn{4}{|l|}{ Age (yrs.) } \\
\hline $25-34$ & $1.60(1.22-2.10)$ & na & $3.13(1.90-5.13)$ \\
\hline$\geq 35$ (ref) & 1.00 & na & 1.00 \\
\hline \multicolumn{4}{|l|}{ Age at sexual debut (yrs.) } \\
\hline $10-14$ & $2.30(1.19-4.45)$ & $2.61(1.27-5.33)$ & na \\
\hline $15-17$ & $1.46(1.07-1.99)$ & $1.26(0.82-1.93)$ & na \\
\hline$\geq 18$ (ref) & 1.00 & 1.00 & na \\
\hline No sexual debut & $1.14(0.55-2.33)$ & na & na \\
\hline \multicolumn{4}{|l|}{ History of STI/PID } \\
\hline Yes & $1.76(1.17-2.64)$ & na & $2.86(1.64-5.00)$ \\
\hline No (ref) & 1.00 & na & 1.00 \\
\hline \multicolumn{4}{|l|}{ Age $x$ history of STI/PID } \\
\hline $25-34$ yrs.x STI/PID & na & $6.38(3.40-11.90)$ & na \\
\hline $25-34$ yrs.x no STI/PID & na & $1.65(1.09-2.49)$ & na \\
\hline$\geq 35$ yrs. $\times$ STI/PID & na & $1.04(0.53-2.07)$ & na \\
\hline$\geq 35$ yrs.x no STI/PID (ref) & na & 1.00 & na \\
\hline \multicolumn{4}{|l|}{ Height (cm) } \\
\hline$\leq 150$ & na & na & $2.47(1.21-5.02)$ \\
\hline$>150$ (ref) & na & na & 1.00 \\
\hline \multicolumn{4}{|l|}{ History of colitis } \\
\hline Yes & $1.83(1.37-2.44)$ & $1.77(1.21-2.59)$ & na \\
\hline No (ref) & 1.00 & 1.00 & na \\
\hline \multicolumn{4}{|l|}{ Chronic urinary tract infections } \\
\hline Yes & na & $1.83(1.25-2.66)$ & $1.86(1.13-3.05)$ \\
\hline No (ref) & na & 1.00 & 1.00 \\
\hline \multicolumn{4}{|l|}{ History of uterine fibroids } \\
\hline Yes & na & na & $3.05(1.45-6.40)$ \\
\hline No (ref) & na & na & 1.00 \\
\hline \multicolumn{4}{|l|}{ BMI $x$ history of fibroids } \\
\hline $\mathrm{BMI} \geq 25 \mathrm{~kg} / \mathrm{m} 2 \times$ fibroids & $4.57(1.93-10.80)$ & na & na \\
\hline $\mathrm{BMI} \geq 25 \mathrm{~kg} / \mathrm{m} 2 \times$ no fibroids & $1.38(0.99-1.93)$ & na & na \\
\hline $\mathrm{BMI}<25 \mathrm{~kg} / \mathrm{m} 2 \times$ fibroids & $0.25(0.02-2.17)$ & na & na \\
\hline $\mathrm{BMI}<25 \mathrm{~kg} / \mathrm{m} 2 \times$ no fibroids (ref) & 1.00 & na & na \\
\hline
\end{tabular}

Notes: ref=reference group. na=not applicable. $P$ ID=pelvic inflammatory disease. $\mathrm{BMI}=$ body mass index.

ucation. Most women (79\%) were married or living in a marital union; 9\% were divorced, separated or widowed; and $12 \%$ were single. Most women had two or more children (83\%), $10 \%$ had one child and $7 \%$ were nulliparous.

Among the 1,007 menstruating women, $40 \%$ had had abdominal pain during menstruation during the previous 12 months; $16 \%$ and $8 \%$, respectively, reported that the pain was moderate or severe (Table 1, page 91). During the previous 12 months, $12 \%$ of the 1,183 sexually active respondents reported having pain during intercourse or within 24 hours afterwards, with $6 \%$ describing their pain as moderate or severe. Among the 1,201 women who had not been pregnant during the previous 12 months, $6 \%$ reported having constant or intermittent pelvic pain that had lasted six months or longer, with symptoms described as severe or moderate by $4 \%$. More than $70 \%$ of women with menstrual pain reported that the onset of pain occurred before age 25. In contrast, most women with intercourse-related pelvic pain reported that it had begun at age 25 or older $(71 \%)$. On average, among women with pelvic pain related to menstruation, the average duration 


\begin{tabular}{|c|c|c|c|}
\hline Characteristic & $\begin{array}{l}\text { Menstrual } \\
\text { paint }\end{array}$ & $\begin{array}{l}\text { Pain with } \\
\text { intercourse }\end{array}$ & $\begin{array}{l}\text { Chronic } \\
\text { pelvic } \\
\text { pain }\end{array}$ \\
\hline $\begin{array}{l}\text { Pain interferes with } \\
\text { work activities }\end{array}$ & $(\mathrm{N}=335)$ & $(\mathrm{N}=122)$ & $(\mathrm{N}=64)$ \\
\hline Yes & 26.0 & 9.8 & 21.9 \\
\hline No & 74.0 & 90.2 & 78.1 \\
\hline $\begin{array}{l}\text { Pain interferes with } \\
\text { home and social } \\
\text { activities }\end{array}$ & $(\mathrm{N}=402)$ & $(\mathrm{N}=146)$ & $(\mathrm{N}=77)$ \\
\hline Yes & 23.6 & 8.9 & 20.8 \\
\hline No & 76.4 & 91.1 & 79.2 \\
\hline $\begin{array}{l}\text { Ever talked with } \\
\text { a physician }\end{array}$ & $(\mathrm{N}=402)$ & $(\mathrm{N}=146)$ & $(\mathrm{N}=77)$ \\
\hline Yes & 25.1 & 22.6 & 40.3 \\
\hline No & 75.0 & 77.4 & 59.7 \\
\hline Used pain medication & $(\mathrm{N}=402)$ & $(\mathrm{N}=146)$ & $(\mathrm{N}=77)$ \\
\hline Yes & 59.0 & 47.3 & 63.6 \\
\hline No & 41.0 & 52.7 & 36.4 \\
\hline Has medical insurance & $(\mathrm{N}=399)$ & $(\mathrm{N}=145)$ & $(\mathrm{N}=77)$ \\
\hline Yes & 70.4 & 67.6 & 70.1 \\
\hline No & 29.6 & 32.4 & 29.9 \\
\hline Total & 100.0 & 100.0 & 100.0 \\
\hline
\end{tabular}

of this condition was 15.8 years (standard deviation, 10.2 years); the average duration in women with pelvic pain related to sexual intercourse was 5.8 years (standard deviation, 6.3 years).

Crude odds ratios for the association of pelvic pain conditions with demographic, reproductive, anthropometric and medical variables are shown in Table 2 (page 92). Being 25-34 at interview, having been younger than 18 at sexual debut, a history of STIs or pelvic inflammatory disease, self-reported uterine fibroids, colitis, chronic urinary tract infections and high BMI $\left(25 \mathrm{~kg} / \mathrm{m}^{2}\right.$ or more) were associated with increased odds of reporting menstrual pain (odds ratios, 1.4-2.3). Being younger than 35 also was as-

\begin{tabular}{|lc|}
\begin{tabular}{|l} 
TABLE 5. Percentage distribution of women, by number and \\
type of pelvic pain conditions
\end{tabular} \\
Number and type & $(\mathrm{N}=1,307)$ \\
\hline One condition & 26.8 \\
Menstrual pain & 21.6 \\
Pain with intercourse & 3.5 \\
Chronic pelvic pain & 1.7 \\
& \\
Two conditions & 7.8 \\
Menstrual pain and pain with intercourse & 5.4 \\
Menstrual pain and chronic pelvic pain & 1.9 \\
Pain with intercourse and chronic pelvic pain & 0.5 \\
& \\
All three conditions & 1.8 \\
& \\
No condition & 63.6 \\
Total &
\end{tabular}

sociated with increased odds of reporting pain during or after intercourse, as were sexual debut before age 15, having had a cesarean section, current IUD use, a history of STIs or pelvic inflammatory disease, having had colitis and having chronic urinary tract infections (1.6-2.7). Being younger than 35, having a history of STIs or pelvic inflammatory disease, having had fibroids, having had colitis, having chronic urinary tract infections and being 150 $\mathrm{cm}$ or shorter in height were associated with increased odds of reporting chronic pelvic pain (1.7-3.8).

\section{Gynecologic Morbidity and the Risk of Pelvic Pain}

- Menstrual pain. In adjusted analyses, younger age, sexual debut before age 18, a history of STIs or pelvic inflammatory disease and self-reported colitis independently increased the odds of menstrual pain (odds ratios, 1.5-2.3; Table 3, page 93). An interaction between uterine fibroids and BMI was observed: Women with fibroids and high BMI ( $25 \mathrm{~kg} / \mathrm{m}^{2}$ or more) had odds of menstrual pain 4.6 times as high as women without fibroids whose BMI was lower than $25 \mathrm{~kg} / \mathrm{m}^{2}$.

- Pelvic pain during or after sexual intercourse. Women with an early sexual debut (at 10-14 years) were significantly more likely than those whose sexual debut was at age 18 or older to experience intercourse-related pelvic pain (adjusted odds ratio, 2.6). Self-reported colitis and self-reported chronic urinary tract infections were associated with increased odds of having pain during and after intercourse ( 1.8 for each). An interaction between age and a history of STIs or pelvic inflammatory disease was also observed: Compared with older women with no history of STIs or pelvic inflammatory disease, women aged 25-34 with a history of STIs or pelvic inflammatory disease had adjusted odds of reporting pain with intercourse 6.4 times as high, while women of the same age who had no history of STIs or pelvic inflammatory disease had adjusted odds of 1.65 .

- Chronic pelvic pain. In adjusted analyses, women younger than 35 and those with a history of STIs or pelvic inflammatory disease, shorter height, chronic urinary tract infections or a history of fibroids had higher odds than women without those characteristics of reporting chronic pelvic pain (odds ratios, 1.9-3.1)

- Interference of pain with daily life and women's use of health care resources. Approximately one-fifth to onequarter of women said that menstrual pain and chronic pelvic pain interfered with their occupational and home activities (Table 4). In the year before the survey, $40 \%$ of women with chronic pelvic pain, $25 \%$ of women with pelvic pain related to menstruation and $23 \%$ of women with pelvic pain during or after intercourse had talked with a physician about their condition, even though about $70 \%$ of women in each group reported having public or private medical insurance. During the previous year, selfmedication or prescription of pain medication was reported by $59 \%$ of women with menstrual pain, $47 \%$ of those with intercourse-related pain and $64 \%$ of those with 
chronic pelvic pain.

- Concurrent pelvic pain. In our study population, 36\% of women experienced some type of pelvic pain (Table 5). Several women reported having multiple types of pelvic pain. Thus, we found that $30 \%$ of women with menstrual pain reported pain with intercourse or chronic pelvic pain or both, while about $70 \%$ of women with either pain with intercourse or chronic pelvic pain reported having other pain pelvic conditions (not shown).

\section{DISCUSSION}

This study is one of the first to evaluate the burden of pelvic pain among reproductive-age women in a representative sample in northern Mexico. We found that pelvic pain is a common condition among adult Mexican women, with $40 \%$ reporting menstrual pain, nearly one in eight reporting pelvic pain during or after intercourse and one in 16 reporting chronic pelvic pain.

The proportion of women in this study who reported menstrual pain in the previous 12 months is comparable to that reported by adult women in both the United States and developing countries. ${ }^{9,10}$ Likewise, the proportion with pain during or within 24 hours after intercourse is similar to the $16 \%$ reported by Laumann and colleagues in a population-based national survey in the United States $;{ }^{4}$ it is also within the range reported in a systematic review of pelvic pain by WHO. ${ }^{9}$ The proportion of women reporting chronic pelvic pain also falls within the range reported in the WHO study (4-43\%).

Some risk factors were common to all three categories of pelvic pain, specifically being younger than 35 and having a history of STIs or pelvic inflammatory disease. Genitourinary symptoms were risk factors for both pain related to intercourse and chronic pelvic pain, while early age at sexual debut and colitis were common risk factors for menstrual pain and intercourse-related pain. These findings are consistent with those of other studies, which have documented that women with one type of pelvic pain tend to have another and that these conditions are associated with the presence of bowel disorders, ${ }^{8}$ genitourinary symptoms ${ }^{8}$ and STIs or pelvic inflammatory disease. ${ }^{4,23}$

Having a history of uterine fibroids appeared as a risk factor for both chronic pelvic pain and menstrual pain. Although studies on high BMI and menstrual pain have produced inconsistent results, ${ }^{25,26}$ our data suggest that high BMI is a risk factor for menstrual pain, primarily among women with a history of uterine fibroids. An endocrine pathway has been documented in previous studies, ${ }^{27,28}$ with obesity resulting in hormonal changes that may increase the risk, number and size of fibroids. The presence of fibroids has been related to heavy bleeding and pelvic pressure or pain. ${ }^{27,28}$ Although pain with intercourse was also associated with uterine fibroids in other population-based studies, ${ }^{29}$ we did not observe an association in our sample.

In this study, early age at sexual debut was a risk factor for both menstrual pain and pain with intercourse. Sexual abuse, which is associated with early age at sexual debut, ${ }^{30,31}$ may account for some part of this relationship. We have reported elsewhere that pain with intercourse is associated with both childhood sexual abuse and sexual assault. ${ }^{32}$ According to other studies, such gynecologic disorders as menstrual pain, excessive menstrual bleeding and sexual dysfunction are associated with a history of sexual assault. ${ }^{33}$ Some research results suggest an association between history of childhood sexual abuse and both menstrual pain and chronic pelvic pain. 23,34

To our knowledge, an association between short stature (150 cm or less) and chronic pelvic pain has not been reported previously. Short stature, which may be the result of genetic or environmental factors, may be correlated with having a narrow pelvis. ${ }^{35}$ Adverse perinatal outcomes are more common in women whose pelvis is narrow and in short women, ${ }^{35,36}$ but data focusing on the effect of pregnancy and childbirth on pelvic pain disorders are scarce. ${ }^{37}$ The long-term impact of obstetric injury associated with short stature on women's gynecologic health deserves further attention.

Menstrual pain is assumed to be normal by many women, who try to diminish its effect in daily life by drinking hot tea, putting a heating pad on the lower abdominal area or taking pain medication. ${ }^{38}$ Analogous information is not available on health routines followed by women with intercourse-related pain and chronic pelvic pain. Given that talking about sexuality is frowned on in Latin American culture, Mexican women probably avoid discussing sexual health problems with physicians. Sexuality is a private issue; thus, women are highly unlikely to disclose any dysfunction related to sexual activity because of a strong sense of shame and embarrassment. ${ }^{39,40}$ Cultural norms surrounding sexual practices may negatively affect women's sexual health because they may prevent women from getting sexual health information and inhibit them from communicating about sexual matters with sexual partners ${ }^{41}$ and health providers. ${ }^{40,42}$ It is not surprising, therefore, that although intercourse-related pain had affected our respondents for an average of six years, only one out of five women had talked with a physician about this condition in the year before the survey.

Compared with women suffering from menstrual pain and pain with intercourse, a substantially higher proportion of those with chronic pelvic pain reported having talked with a physician, having received a diagnosis and having used pain medication. The chronic nature and severity of this pelvic pathology may explain why women were more likely to seek medical help as well as to report that pain interfered with their work and social activities. Similar findings have been reported previously. 6,8

Given that a woman may suffer from more than one type of pelvic pain and that these disorders are often difficult to diagnose, Mexican reproductive health programs should address the complexity of the clinical evaluation of symptoms of pelvic pain. Because we know that health care providers generally wait for women to disclose sexual health problems rather than ask about them directly, we 
suggest a more proactive medical practice in the assessment of pelvic pain, particularly in the evaluation of pain with intercourse. Increasing clinical efforts to address pain and morbidity associated with two of the most common reproductive events in women's lives, menstruation and sexual intercourse, are warranted for women in developing countries.

It is clear that the reproductive health agenda in Mexico should expand to include gynecologic morbidities such as pelvic pain. Given the level of coverage of reproductive health programs in northern Mexico, this region would be an appropriate place to begin a pilot program to screen for and treat gynecologic morbidities. Further studies of the potential relationships among obesity, uterine fibroids and menstrual pain are warranted in the Mexican context, given the high prevalence of obesity among women of reproductive age in this country. ${ }^{43}$

This cross-sectional study focuses on assessing the 12month prevalence of three pelvic pain conditions. Future research in Mexico should consider factors associated with incidence, particularly the joint incidence of multiple painrelated gynecologic conditions in women, given the frequency of their co-occurrence. It is of particular importance to identify cases that represent pain with no organic cause. Additional information is also needed in the Mexican context on women's health-seeking behaviors, as information on women's strategies for diminishing the effect of pelvic pain on daily life is lacking. Qualitative studies would allow characterization of the self-care and selfmedication practices women use for these conditions.

This study had some limitations. Self-reported conditions were not validated by a clinical exam or a review of medical records. However, we had a high response rate, we used a validated questionnaire and our findings were consistent with expected relationships. This study fills an important gap in our knowledge about gynecologic health status and needs of Mexican women. It is the first to provide population-based data on the frequency of three important pelvic pain conditions and their associated risk factors, highlighting the high proportion of women in Mexico who have not consulted a physician about their conditions. Findings from this study illustrate the importance of addressing women's gynecologic complaints within a larger health context.

\section{REFERENCES}

1. Cottingham J and Myntti C, Reproductive health: conceptual mapping and evidence, in: Sen G, George A and Ostlin P, eds., Engendering International Health: The Challenge of Equity, Cambridge, MA, USA: MIT Press, 2002, pp. 85-109.

2. AbouZahr C and Vaughan JP, Assessing the burden of sexual and reproductive ill-health: questions regarding the use of disabilityadjusted life years, Bulletin of the World Health Organization, 2000, 78(5):655-666.

3. Consejo Nacional de Población (CONAPO), Cuadernos de Salud Reproductiva, República Mexicana, Federal District, Mexico: CONAPO, 2000.

4. Laumann EO, Paik A and Rosen RC, Sexual dysfunction in the United States: prevalence and predictors, Journal of the American
Medical Association, 1999, 281(6):537-544.

5. Zondervan KT et al., The community prevalence of chronic pelvic pain in women and associated illness behaviour, British Journal of General Practice, 2001, 51(468):541-547.

6. Mathias SD et al., Chronic pelvic pain: prevalence, health-related quality of life, and economic correlates, Obstetrics \& Gynecology, 1996, $87(3): 321-327$.

7. Kjerulff KH, Erickson BA and Langenberg PW, Chronic gynecological conditions reported by U.S. women: findings from the National Health Interview Survey, 1984 to 1992, American Journal of Public Health, 1996, 86(2):195-199.

8. Zondervan KT et al., Chronic pelvic pain in the community-symptoms, investigations, and diagnoses, American Journal of Obstetrics $\mathcal{E}$ Gynecology, 2001, 184(6):1149-1155.

9. Latthe P et al., WHO systematic review of prevalence of chronic pelvic pain: a neglected reproductive health morbidity, BMC Public Health, 2006, Vol. 6, Art. 177.

10. Harlow SD and Campbell OM, Epidemiology of menstrual disorders in developing countries: a systematic review, BJOG, 2004, 111(1): 6-16.

11. Rosales-Delgado J, Gonzalez-Sicilia C and Aedo-Ocaña O, Laparoscopic findings in endometriosis in women with dysmenorrhea, pelvic pain and sterility, Preliminary note, Ginecología y Obstetricia de México, 1994, 62:389-394 (in Spanish).

12. Pawlowski B, Prevalence of menstrual pain in relation to the reproductive life history of women from the Mayan rural community, Annals of Human Biology, 2004, 31(1):1-8.

13. Pedron-Nuevo $\mathrm{N}$ et al., Incidence of dysmenorrhea and associated symptoms in women aged 12-24 years, Ginecología y Obstetricia de México, 1998, 66(12):492-494 (in Spanish).

14. Rojas-Poceros G et al., Perspective and capacity of gynecologic endoscopy in the hospital ABC: review of 10 years, Perinatología $y$ Reproducción Humana, 2001, 15(4):229-237 (in Spanish).

15. Carranza Lira S et al., The laparoscopic finding in patients with chronic pelvic pain and dysmenorrhea, Ginecología y Obstetricia de México, 1994, 62:82-84 (in Spanish).

16. CONAPO, Indices de Marginación, 2005, Federal District: CONAPO, 2005 , p. 52.

17. Instituto Nacional de Estadística, Geografía e Informatica (INEGI), Conteo de Poblacion y Vivienda 2005, <http://www.inegi.org.mx/est/ contenidos/espanol/sistemas/conteo2005/datos/26/pdf/cpv26_ pob_2.pdf>, accessed Dec. 17, 2009.

18. CONAPO, Prontuario Demográfico 2008: Indicadores Demográficos 2006-2012, <http://www.conapo.gob.mx/ prontuario2008/ 02. pdf>, accessed Dec. 17, 2009.

19. CONAPO, Prontuario Demográfico 2008: Salud Reproductiva y Planificacion Familiar 2006, <http://www.conapo.gob.mx/ prontuario2008/02. pdf>, accessed Dec. 17, 2009.

20. Tamez S and Molina N, The context and process of health care reform in Mexico, in: Fleury S, Belmartino S and Baris E, eds., Reshaping Health Care in Latin America: A Comparative Analysis of Health Care Reform in Argentina, Brazil, and Mexico, Montreal, QC, Canada: International Development Research Center, 2000, pp. 133-153.

21. INEGI, II Conteo de Población y Vivienda 2005, <http://www.inegi. org. $\mathrm{mx} / \mathrm{est} / \mathrm{contenidos/espanol/soc/sis/sisept/default.aspx?t=}$ msoc02\&s=est\&c=1880>, accessed May 28, 2010 .

22. Gobierno del Estado de Sonora, Anuario Estadístico 2003, <http://www.saludsonora.gob.mx/descargas/estadisticas/ AnuarioEstadistico2003.swf>, accessed May 28, 2010.

23. Latthe $P$ et al., Factors predisposing women to chronic pelvic pain: systematic review, BMJ, 2006, 332(7544):749-755.

24. García-Pérez MH, The impact of gynecological morbidity on women's quality of life in northern region of Mexico, unpublished dissertation, Ann Arbor, MI, USA: University of Michigan, 2006.

25. Sundell G, Milsom I and Andersch B, Factors influencing the preva- 
lence and severity of dysmenorrhoea in young women, BJOG, 1990, 97(7):588-594.

26. Harlow SD and Park M, A longitudinal study of risk factors for the occurrence, duration and severity of menstrual cramps in a cohort of college women, BJOG, 1996, 103(11):1134-1142.

27. Marshall LM et al., Risk of uterine leiomyomata among premenopausal women in relation to body size and cigarette smoking, Epidemiology, 1998, 9(5):511-517.

28. Stewart EA, Uterine fibroids, Lancet, 2001, 357(9252):293-298.

29. Lippman SA et al., Uterine fibroids and gynecologic pain symptoms in a population-based study, Fertility and Sterility, 2003, 80(6): 1488-1494.

30. Hindin MJ and Fatusi AO, Adolescent sexual and reproductive health in developing countries: an overview of trends and interventions, International Perspectives on Sexual and Reproductive Health, 2009, 35(2):58-62.

31. Wu ZH, Berenson AB and Wiemann CM, A profile of adolescent females with a history of sexual assault in Texas: familial environment, risk behaviors, and health status, Journal of Pediatric and Adolescent Gynecology, 2003, 16(4):207-216.

32. García-Pérez H and Harlow SD, When coitus produces pain: an exploration of female sexuality in northern Mexico, Salud Publica de Mexico, 2010, 52(2):148-155 (in Spanish).

33. Golding JM, Wilsnack SC and Learman LA, Prevalence of sexual assault history among women with common gynecologic symptoms, American Journal of Obstetrics \& Gynecology, 1998, 179(4):1013-1019.

34. Lampe A et al., Chronic pain syndromes and their relation to childhood abuse and stressful life events, Journal of Psychosomatic Research, 2003, 54(4):361-367.

35. Camilleri AP, The obstetric significance of short stature, European Journal of Obstetrics \& Gynecology and Reproductive Biology, 1981, 12(6):347-356.

36. Kappel B et al., Short stature in Scandinavian women. An obstetrical risk factor, Acta Obstetricia et Gynecologica Scandinavica, 1987, 66(2):153-158.

37. Mens JM et al., Understanding peripartum pelvic pain. Implications of a patient survey, Spine, 1996, 21(11):1363-1369.

38. Denman Champion CA, Mujeres, Maquila y Embarazo. Prácticas de Atención de Madres-Trabajadoras en Nogales, Sonora, México, Hermosillo, Mexico: College of Sonora, 2008.

39. Amuchástegui A and Rivas M, Subjective construction of sexual citizenship in Mexico: gender, heteronormativity and ethics, in: Szasz I y Salas G, eds., Sexualidad, Derechos Humanos y Ciudadanía. Diálogos Sobre un Proyecto en Construcción, Federal District, Mexico: College of Mexico, 2008, pp. 57-133 (in Spanish).

40. Davila YR, The social construction and conceptualization of sexual health among Mexican American women, Research and Theory for Nursing Practice, 2005, 19(4):357-368.

41. Amuchástegui A, To know or not to know about sex: dilemmas of female sexual activity to Mexican youths, in: Szasz I and Lerner S, eds., Sexualidad en México: Algunas Aproximaciones Desde la Perspectiva de las Ciencias Sociales, Federal District, Mexico: College of Mexico, 2005, pp. 107-135 (in Spanish).

42. Hirsch JS et al., The social constructions of sexuality: marital infidelity and sexually transmitted disease-HIV risk in a Mexican migrant community, American Journal of Public Health, 2002, 92(8):1227-1237.

43. Instituto Nacional de Salud Publica (INSP), Encuesta Nacional de Salud y Nutrición 2006: Resultados por Entidad Federativa, Sonora, Mexico: INSP, 2007

\section{RESUMEN}

Contexto: Hasta hace poco, las estrategias para avanzar la salud reproductiva se han centrado en un número restringido de indicadores de morbilidad, especialmente en aquellos aso- ciados con enfermedades que conllevan un riesgo de vida. Sin embargo, las morbilidades ginecológicas que producen dolor pélvico, aunque no representan un riesgo de vida, sí imponen una carga sustancial para la salud debido a su potencial para reducir el bienestar general de las mujeres.

Métodos: En 2005, se realizó un estudio poblacional transversal en Hermosillo, México, para evaluar las condiciones auto-reportadas de dolor pélvico en una muestra aleatoria de 1,307 mujeres de 25-54 años de edad. Se calculó la prevalencia a 12 meses de cada condición y se utilizó regresión logística para evaluar la asociación entre el dolor pélvico y las características sociales, demográficas, antropométricas y reproductivas, así como otras condiciones médicas.

Resultados: En las 1,007 mujeres que todavía menstruaban, la prevalencia del dolor pélvico durante la menstruación fue del 40\%. El 12\% de las 1,183 mujeres sexualmente activas, reportaron dolor pélvico durante o después del coito. De las 1,201 mujeres no embarazadas, el 6\% reportaron dolor pélvico crónico. En los análisis ajustados, tener una edad menor (25-34 años) o una historia de ITS o de enfermedad inflamatoria pélvica (EIP), estuvo asociado con un mayor riesgo de dolor durante la menstruación y dolor pélvico crónico (razones de momios, 1.6-3.1). Un indicador de la interacción entre la edad menor y una historia de ITS o EIP, estuvo asociado con un riesgo elevado de dolor pélvico vinculado con el coito (6.4). Se reportaron como factores que interfieren con las actividades diarias el dolor pélvico crónico y el dolor durante la menstruación, con mayor frecuencia que el dolor pélvico asociado con la relación sexual. La proporción de mujeres que habian conversado con un médico sobre su condición fue la mayor en aquellas con dolor pélvico crónico (40\%).

Conclusión: El dolor pélvico asociado con la menstruación, el dolor pélvico durante o después del coito y el dolor pélvico crónico, son quejas comunes en mujeres mexicanas en edad reproductiva. Los proveedores de servicios de salud deben poner una mayor atención a estas condiciones.

\section{RÉSUMÉ}

Contexte: Voici peu encore, l'ordre du jour de la santé génésique se concentrait encore sur un nombre limité d'indicateurs de morbidité associés, en particulier, aux maladies graves. Les morbidités gynécologiques sources de douleur pelvienne, bien que non mortelles, imposent cependant un lourd fardeau quand on sait le potentiel qu'elles ont de réduire le bien-être général des femmes.

Méthodes: En 2005, une étude transversale en population a été effectuée à Hermosillo (Mexique) dans le but d'évaluer les conditions de douleur pelvienne autodéclarées dans un échantillon aléatoire de 1.307 femmes âgées de 25 à 54 ans. La prévalence sur 12 mois de chaque condition a été calculée et l'association entre la douleur pelvienne, les caractéristiques sociodémographiques, anthropométriques et génésiques et d'autres affections médicales a été évaluée par régression logistique.

Résultats: La prévalence sur 12 mois de la douleur pelvienne pendant la menstruation s'est révélée de $40 \%$ parmi 1.007 femmes réglées. La douleur pelvienne pendant ou après les rapports sexuels a été déclarée par 12\% des 1.183 répondantes 
sexuellement actives. Parmi les 1.201 femmes non enceintes, $6 \%$ ont signalé une douleur pelvienne chronique. Dans les analyses corrigées, l'âge moindre (25 à 34 ans) et les antécédents d'IST ou de maladie inflammatoire pelvienne (MIP) sont associés à un risque accru de douleur pendant la menstruation et de douleur pelvienne chronique (rapport de probabilités, 1,6-3,1). Un terme d'interaction d'âge moindre et d'antécédents d'IST ou MIP est associé à un risque élevé de douleur pelvienne liée aux rapports sexuels $(6,4)$. La douleur pelvienne chronique et la douleur pendant la menstruation sont décrites plus souvent comme perturbant les activités quotidiennes que la douleur pelvienne liée aux rapports sexuels. La proportion des femmes qui avaient parlé de leur condition à un médecin s'est révélée la plus élevée parmi celles atteintes de douleur pelvienne chronique (40\%).

Conclusion: La douleur pelvienne associée à la menstruation, celle ressentie pendant ou après les rapports sexuels et la douleur pelvienne chronique représentent des plaintes courantes parmi les Mexicaines en âge de procréer. Les prestataires de santé devraient prêter davantage attention à ces affections.

\section{Acknowledgments}

This article is based on research supported by grant D43 TW01276 from the National Institutes of Health/Fogarty International Center and grant 1000-1241 from the Ford Foundation.

Author contact: hilda.garcia@asu.edu

\section{Correction}

In "Wanted and Unwanted Fertility in Bolivia: Does Ethnicity Matter?" by Catherine McNamee [2009, 35(4): 166-175], the wanted total fertility rates and the unwanted total fertility rates reported in the abstract and on p. 170 are incorrect. The correct estimates for total wanted fertility, using one-year measures, are 1.5 for indigenous women and 1.7 for nonindigenous women; the correct estimates for total unwanted fertility are 2.8 and 1.4 , respectively. The article's conclusion that unwanted fertility accounts for virtually all the difference in total fertility between indigenous and nonindigenous women remains unchanged. The corrected article is available on our Web site. 